\title{
Retrospective Capital Gains Taxation in the Real World
}

\author{
FRANCESCO MENONCIN \\ PAOLO M. PANTEGHINI
}

\section{CESIFO WORKING PAPER NO. 2674 \\ CATEGory 1: PubliC FinANCE \\ JUNE 2009}

Presented at CESifo Area Conference on Public Sector Economics, April 2009

\footnotetext{
An electronic version of the paper may be downloaded

- from the SSRN website:

www.SSRN.com

- from the RePEc website:

- from the CESifo website:

www.RePEc.org

www.CESifo-group.org/wp
} 


\title{
Retrospective Capital Gains Taxation in the Real World
}

\begin{abstract}
In this article, we analyze Auerbach's (1991) proposal of a retrospective capital gains tax, which is equivalent to an accrual tax on an ex-ante basis. Using a continuous-time model with stochastic interest rates, we prove that equivalence holds even if the risk-free asset return is correlated with other risky assets' returns. However, equivalence fails to hold on an ex-post basis. In other words, if an investor faces a huge gain (loss), the effective tax rate under this system is less (higher) than that what would be due under an accrual tax system. This leads to a fairness problem. For this reason, we also find the conditions that ensure equivalence on an ex-post basis. As will be shown, however, ex-post equivalence can be achieved only if a huge amount of information is available, making its implementation a hard task.
\end{abstract}

JEL Code: H25, H32.

Keywords: capital gains, risk, taxation.

Francesco Menoncin

Department of Economics

University of Brescia

Via S. Faustino 74/B

Italy-25122 Brescia

menoncin@eco.unibs.it
Paolo M. Panteghini

Department of Economics

University of Brescia

Via S. Faustino 74/B

Italy-25122 Brescia

panteghi@eco.unibs.it

We would like to thank Michael Stimmelmayr and other participants of the 2009 CESifo Area Conference on Public Sector Economics for their helpful comments and suggestions. 


\section{Introduction}

Capital gains can be taxed either at accrual or at realization. The former method is preferable from a fairness point of view, as it taxes capital gains when they accrue, thereby providing a more precise measure of a taxpayer's ability to pay. Under this system, the taxpayer should fill an income tax return accounting for all changes in the assets' values. This would be easy if, during this period, shares were sold to other shareholders. Otherwise, the taxpayer would have to calculate changes in his/her portfolio on the basis of data that is often imprecise. In particular, it would not be easy to evaluate an asset that is not publicly traded (see Green and Sheshinski, 1979). ${ }^{1}$ Given this limitation, most countries have therefore opted for a realization-based capital gains tax. ${ }^{2}$ However, under this method, an investor is "locked-in", i.e., is encouraged to delay selling assets to save taxes (see, e.g., Constantinides, 1983).

In order to neutralize the lock-in effect and at the same time, implement a realization-based system, Auerbach (1991) proposes a retrospective capital gains tax device, which raises the effective tax burden if realization is postponed. He shows that this system is equivalent to an accrual method on an ex-ante perspective. By denoting this equivalence as holding-period neutrality, he proves that an investor is no longer encouraged to delay realization. Moreover, the Auerbach tax overcomes the informational problems arising from Vickrey's (1939) original proposal, which required the availability of information on past assets' price. Indeed, the retrospective tax formula simply requires asset's current price and the spot interest rate during the holding period. ${ }^{3}$

Auerbach's (1991) proposal suffers from at least two limitations. Firstly,

\footnotetext{
${ }^{1}$ The accrual method has another limitation if an investor is subject to liquidity constraints. As the tax burden may occur in a period when the taxpayer matures but does not realize the capital gains, a liquidity problem could arise. For instance, the taxpayer might be forced to sell part of his/her assets, against his/her own wishes, in order to pay the taxes.

${ }^{2}$ Italy is one of the few exceptions that implemented the accrual method for the management of non-qualified shareholdings in listed companies (see Bonzani et al., 2002; Alworth et al., 2003).

${ }^{3}$ Auerbach and Bradford (2004) merge Auerbach's (1991) and Bradford's (1997) findings and obtain a generalized cash-flow tax system. They show that from both an investor's and the government's point of view, their joint proposal is equivalent to a pure accrual tax system on an ex-ante basis.
} 
it is based on the assumption that the risk-free interest rate is deterministic, although he states that the quality of results does not change if the risk-free asset is a "zero-beta" one, i.e., "carries no risk premium" (footnote 2, p. 169). Auerbach (1991) also implicitly assumes that risky asset returns are serially uncorrelated, i.e., evolve according to a random walk. As pointed out by Fama and French (2004) however, the "zero-beta" assumption is not supported by empirical evidence. As shown, e.g., by Shiller and Beltratti (1992), there is a negative correlation between stock returns and changes in interest rates. Peersman and Smets (2005) also show that monetary policy may deeply affect stock market returns. In particular, interest rate pegging strategies by central bankers have a heterogeneous impact on industries' returns. Moreover, Campbell and Shiller (1988) and Campbell (2008) show that excess stock returns can be predicted by means of lagged financial variables.

The second limitation of the retrospective tax device is given by the absence of ex-post equivalence. In other words, if an investor faces a huge gain, the effective tax rate under this system is less than that what would be due under an accrual tax system. The converse is true if an investor faces a loss. Auerbach (1991) argues that the absence of ex-post equivalence may be a problem in terms of fairness. In order to tackle this issue, Kaplow (1994) applies a two-period model and shows that the retrospective tax is neutral from an ex-post perspective, if the government can implement an optimal portfolio strategy. The reasoning behind this result is as follows: if the government can make the same portfolio strategies as individual investors (in each state of the world), it is therefore able to make the investors' actual net positions the same as they would be under an accrual tax. ${ }^{4} \mathrm{~A}$ similar result can be obtained by letting fiscal policy be state-contingent, in line with Zhu (1992).

In this article we deal with Auerbach's proposal, by assuming a more realistic framework where the spot interest rate is stochastic and may be correlated with risky asset returns. Moreover, we account for Kaplow's caveat that "[a]llowing many periods [...] makes the definition and practical implementation of ex ante and ex post concepts more complex" (footnote 14, p. 797). For this reason, we will apply a continuous-time framework.

We have two results. Firstly, we will show that ex-ante holding-period neutrality holds in a more realistic setting, where the risk-free asset is not

\footnotetext{
${ }^{4}$ For further details see Weisbach (2004).
} 
necessarily a "zero-beta" security. Secondly, we will prove that ex-post equivalence can be achieved by applying a state-contingent tax rule. To do so, however, we need information not only on current but also on past prices: this leads to the same critique raised on Vickrey's (1939) proposal and therefore, suffers from severe implementation problems.

The structure of this article is as follows. Section 2 introduces and discusses the assumptions of the model used to address the capital gains tax problem. Section 3 contains the equivalence results on both an ex-ante and ex-post basis. Section 4 summarizes our findings and discusses their policy implications.

\section{A continuous-time model}

In line with Auerbach (1991), we introduce a partial-equilibrium model, with continuous time. For simplicity, we assume the existence of only two assets: a risk-free asset and a risky one.

We define $S(t)$ and $r(t)$ as the price of the risky asset and the spot interest rate of the risk-free asset at time $t$, respectively. In a complete market we therefore have

$$
S(t)=\mathbb{E}_{t}^{\mathbb{Q}}\left[S(T) e^{-\int_{t}^{T} r(s) d s}\right], \quad \forall t \geq T,
$$

where $\mathbb{Q}$ is the (unique) risk-neutral probability.

Although the debate on financial phenomena is still lively and controversial, we cannot disregard the fact that there may be non-zero correlation between interest rates and risky assets, and/or some serial correlation on asset returns. ${ }^{5}$ For this reason we introduce the following:

Assumption 1 The value of the risky asset evolves as follows:

$$
\frac{d S(t)}{S(t)}=r(t) d t+\underset{1 \times k}{\sigma(t, S)^{\prime}} d \underset{k \times 1}{W(t)^{\mathbb{Q}}}, \quad S\left(t_{0}\right)=S_{0}>0
$$

\footnotetext{
${ }^{5}$ Canova and De Nicolò (2003) focus on G-7 countries and find that "real equity returns and the real risk-free rate do not significantly move together" (p. 227). However, they show that over certain subsamples, there is a significantly negative correlation between these variables. Moreover, when they account for price dynamics, they find a negative correlation between the real risk-free rate and price dynamics. Ang and Bekaert (2007) show that interest rates (rather than other past financial variables) can predict stock returns.
} 
where $S_{0}$ is known at time $t_{0}, \sigma(t, S)^{\prime} \sigma(t, S) \in \mathbb{R}$ is the variance of an asset's instantaneous return, $W^{\mathbb{Q}}(t)$ is a $k$ dimension Wiener process under the risk-neutral probability measure $\mathbb{Q}$, and the prime denotes transposition.

Assumption 2 The spot interest rate $r(t)$ evolves as follows:

$$
d r(t)=\mu_{r}(t, r) d t+\underset{1 \times k}{\sigma_{r}(t, r)^{\prime}} \underset{k \times 1}{W(t)^{\mathbb{Q}},}
$$

where $\mu_{r}(t, r)$ and $\sigma_{r}(t, r)$ are the drift and the instantaneous standard deviation, respectively.

According to Assumption 1, the dynamics of $S(t)$ may be characterized by serial correlation. Assumption 2 lets the spot rate be stochastic. According to Merton (1973), the risk-free asset should be denoted as "instantaneously risk-less asset" (p. 874). In other words, the risk-free interest rate is known ahead of time for one instant $d t$ (from $t$ to $t+d t$ ). However, it may change later (i.e., at time $t+2 d t$ ), and is therefore unknown in the future. ${ }^{6}$

Let us next find the conditions that make a realization-based system equivalent to an accrual one from either an ex-ante and ex-post perspective. Denoting the tax factor as $\theta(t) \equiv 1-\tau_{c}(t) \leq 1$, where $\tau_{c}(t)$ is the effective capital gains tax rate at time $t$, and assuming that a risky asset is bought at time $t_{0}$ and sold at $t>t_{0}$, the after-tax value is equal to

$$
S(t) \theta(t) \text {. }
$$

Given the statutory tax rate on interest income $\tau$, we can write the following:

Definition 1 On an ex-ante basis, a retrospective tax device and an accrual system are equivalent if

$$
\mathbb{E}_{t}^{\mathbb{Q}}\left[\frac{d(\theta(t) S(t))}{\theta(t) S(t)}\right]=(1-\tau) r(t) d t .
$$

In line with Auerbach (1991), Definition 1 says that ex-ante equivalence holds if the after-tax return on asset $S(t)$ is, on average, equal to the after-tax return on the risk-free asset, i.e., $(1-\tau) r(t)$.

\footnotetext{
${ }^{6}$ The dynamics of the risk-free rate can also be examined in a general equilibrium model. See, e.g., Vasicek (2005). For a discussion of the equilibrium interest rate under a comprehensive income tax regime see Menoncin and Panteghini (2008).
} 
Given Assumptions 1 and 2, however, the likelihood that the after-tax return $\frac{d(\theta(t) S(t))}{\theta(t) S(t)}$ is just equal to $(1-\tau) r(t)$ is nil. This means that tax liabilities may differ on an ex-post basis. For this reason we also introduce the following:

Definition 2 On an ex-post basis, the retrospective tax device is equivalent to an accrual system if

$$
\frac{d(\theta(t) S(t))}{\theta(t) S(t)}=(1-\tau) r(t) d t
$$

According to Definition 2, ex-post equivalence holds if the after-tax return on asset $S(t)$, under $\mathbb{Q}$, is equal to the after-tax return on the risk-free asset, in any state of the world. In this case, tax liabilities are always the same.

\section{Equivalence results}

Let us next find the conditions under which equivalence is met. To do so, we let the tax factor evolve as follows:

$$
\frac{d \theta(t)}{\theta(t)}=\mu_{\theta}(t) d t+\sigma_{\theta}(t)^{\prime} d W^{\mathbb{Q}},
$$

where $\mu_{\theta}(t)$ and $\sigma_{\theta}(t)$ are two tax tools. In particular, $\mu_{\theta}(t)$ is a drift component that can be chosen by the government to let the tax factor follow a deterministic trend. By adjusting $\mu_{\theta}(t)$, a policymaker can therefore implement a deterministic rule and obtain the ex-ante-equivalence condition (4). The term $\sigma_{\theta}(t)$ is a state-contingent tool that can offset any shock $d W^{\mathbb{Q}}$. This means that, by choosing $\sigma_{\theta}(t)$, a government can achieve condition (6) and thus obtain ex-post equivalence.

Using rule (6) we can prove the following:

Proposition 1 Denoting $\theta_{a}(t)$ as the relevant tax factor, ex-ante equivalence holds if:

$$
\begin{aligned}
& \frac{d \theta_{a}(t)}{\theta_{a}(t)}=-\tau r(t) d t \\
& \theta_{a}\left(t_{0}\right)=1 .
\end{aligned}
$$


Proof. Using (2) and (6), let us differentiate $S(t) \theta(t)$, so that:

$$
\begin{aligned}
\frac{d(S(t) \theta(t))}{S(t) \theta(t)}= & \frac{d S(t)}{S(t)}+\frac{d \theta(t)}{\theta(t)}+\frac{d S(t)}{S(t)} \frac{d \theta(t)}{\theta(t)} \\
= & \left(r(t)+\mu_{\theta}(t)+\sigma(t, S)^{\prime} \sigma_{\theta}(t)\right) d t \\
& +\left(\sigma(t, S)+\sigma_{\theta}(t)\right)^{\prime} d W^{\mathbb{Q}} .
\end{aligned}
$$

Substituting (8) into (4) gives:

$$
\mathbb{E}_{t}^{\mathbb{Q}}\left[\frac{d(\theta(t) S(t))}{\theta(t) S(t)}\right]=(1-\tau) r(t) d t=\left(r(t)+\mu_{\theta}(t)+\sigma(t, S)^{\prime} \sigma_{\theta}(t)\right) d t .
$$

If we set $\sigma_{\theta}(t)=\mathbf{0}$ and rearrange (9) we obtain $\mu_{\theta}(t)=-\tau r(t)$. Substituting this result into (6) gives the deterministic rule (7). The proposition is therefore proven.

Proposition 1 derives a sufficient condition for ex-ante equivalence to hold. In particular, solving (9) gives the same deterministic rule as that obtained by Auerbach (1991), i.e.,

$$
\theta_{a}(t)=e^{-\int_{t_{0}}^{t} \tau r(u) d u}
$$

where $\theta_{a}(t)$ is monotonically decreasing in time. ${ }^{7}$ This implies that Auerbach's (1991) result holds in a more general setting, where the risk-free asset must not be a zero-beta security and risky asset returns may be serially correlated. The reasoning behind this result is simple: as shown in the proof of Proposition 1 , if we set $\sigma_{\theta}(t)=\mathbf{0}$, we obtain a deterministic rules that just requires knowledge of variables $r(t)$ and $S(t)$. Since both are known at time $t$, correlation does not matter.

It is worth noting that Auerbach and Bradford (2004) addressed the implementation problems arising from the stochastic dynamics of interest rates. They proposed two alternative systems, both aimed at calculating the tax liability on ex-post basis. In line with Bradford's (1997) proposal, one possibility would be to postpone resolving the tax liability until the arrival of a gain reference date. An alternative option would be to choose a gain reference date that would always be in the past for the affected investor. Of course, Proposition 1 shows that these devices are not necessary in order for ex-ante equivalence to hold.

\footnotetext{
${ }^{7}$ Auerbach's (1991) Eq. (6) (on p. 170) is equal to (10).
} 
As pointed out rule (7) does not ensure ex-post equivalence. To see this we apply Itô's lemma to (10) and find

$$
\frac{d\left(S(t) \theta_{a}(t)\right)}{S(t) \theta_{a}(t)}=(1-\tau) r(t) d t+\sigma(t, S)^{\prime} d W^{\mathbb{Q}}(t) .
$$

This means that, under a retrospective system, if an investor faces a huge gain (i.e., $d W^{\mathbb{Q}}(t)>0$ ), the effective tax burden is less than what would be due under an accrual tax, and vice versa. In order to ensure the same after-tax return in any state of the world, a policymaker should implement a state-contingent tax. Using Definition 2 we can prove the following:

Proposition 2 Denoting $\theta_{p}(t)$ as the relevant tax factor, ex-post equivalence holds if and only if

$$
\begin{aligned}
& \frac{d \theta_{p}(t)}{\theta_{p}(t)}=\left(-\tau r(t)+\sigma(t, S)^{\prime} \sigma(t, S)\right) d t-\sigma(t, S)^{\prime} d W^{\mathbb{Q}}(t) \\
& \theta_{p}\left(t_{0}\right)=1
\end{aligned}
$$

Proof. Condition (5) holds if, given (8), the following equality holds

$$
\begin{aligned}
\frac{d(\theta(t) S(t))}{\theta(t) S(t)}= & (1-\tau) r(t) d t=\left(r(t)+\mu_{\theta}(t)+\sigma(t, S)^{\prime} \sigma_{\theta}(t)\right) d t(12) \\
& +\left(\sigma(t, S)+\sigma_{\theta}(t)\right)^{\prime} d W^{\mathbb{Q}} .
\end{aligned}
$$

This means that (12) holds only if the drift and diffusion coefficients $\mu_{\theta}(t)$ and $\sigma_{\theta}(t)$ are such that

$$
\begin{aligned}
\sigma(t, S)+\sigma_{\theta}(t) & =\mathbf{0}, \\
r(t)+\mu_{\theta}(t)+\sigma(t, S)^{\prime} \sigma_{\theta}(t) & =(1-\tau) r(t) .
\end{aligned}
$$

Rearranging this two-equation system gives

$$
\begin{aligned}
\sigma_{\theta}(t) & =-\sigma(t, S), \\
\mu_{\theta}(t) & =-\tau r(t)+\sigma(t, S)^{\prime} \sigma(t, S) .
\end{aligned}
$$

Substituting these results into (6) gives (11). The proposition is therefore proven.

Proposition 2 derives a necessary and sufficient condition for ex-post equivalence to hold. As can be seen, rule (11) is state-contingent, since 
the equality $\sigma_{\theta}(t)=-\sigma(t, S)$ must hold. In other words, the tax tool $\sigma_{\theta}(t)$ is such that any asset price shock is just offset, so that the actual return is always $(1-\tau) r(t)$ in any time interval $(1-\tau) r(t)$. Solving the stochastic differential equation (11) gives

$$
\theta_{p}(t)=e^{\int_{t_{0}}^{t}\left(-\tau r(s)+\frac{1}{2} \sigma(s, S)^{\prime} \sigma(s, S)\right) d s-\int_{t_{0}}^{t} \sigma(s, S)^{\prime} d W^{\mathbb{Q}}(s)} .
$$

As can be seen in (13), the calculation of $\theta_{p}(t)$ requires the knowledge of past asset prices. Moreover, we need to know the value of $\sigma(s, S)$ for any $s \in\left[t_{0}, t\right]$. This is extremely difficult. Of course the equivalence result is an even harder task if: i) risky asset returns are heteroschedastic (i.e., $\sigma$ depends on $S$ ) and ii) some assets are not listed. In sum we can say that the state-contingent rule (12) is informationally very demanding and is therefore to the same critique as that based on Vickrey's (1939) original proposal.

\section{Conclusion}

In this article, we have analyzed Auerbach's (1991) proposal of a retrospective capital gains tax. Using a continuous-time model, with stochastic interest rates, we have both good and bad news. The good news is that ex-ante holding-period neutrality holds in a more realistic framework, where the riskfree interest rate is correlated with risky asset returns. Contrary to what Auerbach and Bradford (2004) maintain, no ad hoc adjustments are needed to account for the stochastic dynamics of interest rates. The bad news is that, due to severe information problems, designing a state-contingent rule that ensures ex-post equivalence is a hard task.

\section{References}

[1] Alworth J., G. Arachi and R. Hamaui (2003), "What's Come to Perfection Perishes": Adjusting Capital Gains Taxation in Italy, National Tax Journal, 56, pp. 197-219.

[2] Ang A. and G. Bekaert (2007), Stock Return Predictability: Is It There?, Review of Financial Studies, 20, pp. 651-707.

[3] Auerbach A.J. (1991), Retrospective Capital Gains Taxation, American Economic Review, 81, pp. 167-178. 
[4] Auerbach A.J. and D.F. Bradford (2004), Generalized Cash-Flow Taxation, Journal of Public Economics, 88, pp. 957-980.

[5] Bonzani E., P.M. Panteghini and F. Venturi (2002), Italy's Taxation of Financial Income at A Crossroads, Tax Notes International, November, pp. 469-473.

[6] Bradford D.F. (1997), Fixing Realization Accounting: Symmetry, Consistency and Correctness in the Taxation of Financial Instruments, Tax Law Review, Summer 1995, 50, pp. 731-785.

[7] Campbell J.Y. (2008), Estimating the Equity Premium, Canadian Journal of Economics, 41, pp. 1-21.

[8] Campbell J.Y. and R.J. Shiller (1988), The Dividend-Ratio and Expectations of Future Dividends and Discount Factors, Review of Financial Studies, 1, pp. 195-228.

[9] Canova F. and G. De Nicolò (2003), The Properties of the Equity Premium and the Risk-Free Rate: An Investigation, IMF Staff Papers, 50, pp. 222-249.

[10] Constantinides G.M. (1983), Capital Market Equilibrium with Personal Tax, Econometrica, 51, pp. 611-636.

[11] Fama E.F. and K.R. French (2004), The Capital Asset Pricing Model: Theory and Evidence, Journal of Economic Perspectives, 18, pp. 25-46.

[12] Green J.R. and E. Sheshinski (1979), Optimal Capital-Gains Taxation under Limited Information, Journal of Political Economy, 86, pp. 11431158 .

[13] Kaplow L. (1994), Taxation and Risk Taking: A General Equilibrium Perspective, National Tax Journal, 47, pp. 789-798.

[14] Menoncin F. and P.M. Panteghini (2008), The Johansson-Samuelson Theorem in General Equilibrium: A Rebuttal, CESifo W.P. Series No. 2352.

[15] Merton R.C. (1973), An Intertemporal Capital Asset Pricing Model, Econometrica, 41, pp. 867-887. 
[16] Peersman G. and F. Smets (2005), The Industry Effects of Monetary Policy in the Euro Area, The Economic Journal, 115, pp. 319-342.

[17] Shiller R.J. and A.E. Beltratti (1992), Stock Prices and Bond Yields: Can Their Comovements Be Explained in terms of Present Value Models?, Journal of Monetary Economics, 30, pp. 25-46.

[18] Vasicek O.A. (2005), The Economics of Interest Rates, Journal of Financial Economics, 76, pp. 293-307.

[19] Vickrey W. (1939), Averaging of Income for Income-Tax Purposes, Journal of Political Economy, 47, pp. 379-397.

[20] Weisbach D.A. (2004), Taxation and Risk-Taking with Multiple Tax Rates, National Tax Journal, 57, pp. 229-243.

[21] Zhu X. (1992), Optimal Fiscal Policy in a Stochastic Growth Model, Journal of Economic Theory, 58, pp. 250-289. 


\section{CESifo Working Paper Series}

for full list see www.cesifo-group.org/wp

(address: Poschingerstr. 5, 81679 Munich, Germany, office@cesifo.de)

2613 Michael Melvin, Christian Saborowski, Michael Sager and Mark P. Taylor, Bank of England Interest Rate Announcements and the Foreign Exchange Market, April 2009

2614 Marie-Louise Leroux, Pierre Pestieau and Gregory Ponthiere, Should we Subsidize Longevity?, April 2009

2615 Ronald MacDonald, Lukas Menkhoff and Rafael R. Rebitzky, Exchange Rate Forecasters’ Performance: Evidence of Skill?, April 2009

2616 Frederick van der Ploeg and Steven Poelhekke, The Volatility Curse: Revisiting the Paradox of Plenty, April 2009

2617 Axel Dreher, Peter Nunnenkamp, Hannes Öhler and Johannes Weisser, Acting Autonomously or Mimicking the State and Peers? A Panel Tobit Analysis of Financial Dependence and Aid Allocation by Swiss NGOs, April 2009

2618 Guglielmo Maria Caporale, Roman Matousek and Chris Stewart, Rating Assignments: Lessons from International Banks, April 2009

2619 Paul Belleflamme and Martin Peitz, Asymmetric Information and Overinvestment in Quality, April 2009

2620 Thomas Dohmen, Armin Falk, David Huffman and Uwe Sunde, Are Risk Aversion and Impatience Related to Cognitive Ability?, April 2009

2621 Yin-Wong Cheung and Xingwang Qian, The Empirics of China's Outward Direct Investment, April 2009

2622 Frédérique Bec and Christian Gollier, Assets Returns Volatility and Investment Horizon: The French Case, April 2009

2623 Ronnie Schöb and Marcel Thum, Asymmetric Information Renders Minimum Wages Less Harmful, April 2009

2624 Martin Ruf and Alfons J. Weichenrieder, The Taxation of Passive Foreign Investment Lessons from German Experience, April 2009

2625 Yao Li, Borders and Distance in Knowledge Spillovers: Dying over Time or Dying with Age? - Evidence from Patent Citations, April 2009

2626 Jim Malley and Ulrich Woitek, Technology Shocks and Aggregate Fluctuations in an Estimated Hybrid RBC Model, April 2009

2627 Jin Cao and Gerhard Illing, Endogenous Systemic Liquidity Risk, April 2009 
2628 Thiess Buettner and Bjoern Kauder, Revenue Forecasting Practices: Differences across Countries and Consequences for Forecasting Performance, April 2009

2629 Håkan Selin, The Rise in Female Employment and the Role of Tax Incentives - An Empirical Analysis of the Swedish Individual Tax Reform of 1971, April 2009

2630 Nick Johnstone and Ivan Hascic, Environmental Policy Design and the Fragmentation of International Markets for Innovation, April 2009

2631 Spiros Bougheas, Richard Kneller and Raymond Riezman, Optimal Education Policies and Comparative Advantage, April 2009

2632 Jay Pil Choi and Heiko Gerlach, Multi-Market Collusion with Demand Linkages and Antitrust Enforcement, April 2009

2633 Thor O. Thoresen, Income Mobility of Owners of Small Businesses when Boundaries between Occupations are Vague, April 2009

2634 Guido Schwerdt and Amelie C. Wuppermann, Is Traditional Teaching really all that Bad? A Within-Student Between-Subject Approach, April 2009

2635 Kurt R. Brekke, Luigi Siciliani and Odd Rune Straume, Hospital Competition and Quality with Regulated Prices, April 2009

2636 Peter Diamond, Taxes and Pensions, April 2009

2637 Shoshana Grossbard, How “Chicagoan” are Gary Becker’s Economic Models of Marriage?, May 2009

2638 Roland Strausz, Regulatory Risk under Optimal Incentive Regulation, May 2009

2639 Holger Zemanek, Ansgar Belke and Gunther Schnabl, Current Account Imbalances and Structural Adjustment in the Euro Area: How to Rebalance Competitiveness, May 2009

2640 Harald Hau and Marcel Thum, Subprime Crisis and Board (In-)Competence: Private vs. Public Banks in Germany, May 2009

2641 Martin Halla, Mario Lackner and Friedrich G. Schneider, An Empirical Analysis of the Dynamics of the Welfare State: The Case of Benefit Morale, May 2009

2642 Balázs Égert, Infrastructure Investment in Network Industries: The Role of Incentive Regulation and Regulatory Independence, May 2009

2643 Christian Gollier, Expected Net Present Value, Expected Net Future Value, and the Ramsey Rule, May 2009

2644 Sören Blomquist and Håkan Selin, Hourly Wage Rate and Taxable Labor Income Responsiveness to Changes in Marginal Tax Rates, May 2009 
2645 Dominique Demougin, Oliver Fabel and Christian Thomann, Implicit vs. Explicit Incentives: Theory and a Case Study, May 2009

2646 Francesco C. Billari and Vincenzo Galasso, What Explains Fertility? Evidence from Italian Pension Reforms, May 2009

2647 Kjell Arne Brekke, Karen Evelyn Hauge, Jo Thori Lind and Karine Nyborg, Playing with the Good Guys - A Public Good Game with Endogenous Group Formation, May 2009

2648 Guglielmo Maria Caporale and Luis A. Gil-Alana, Multi-Factor Gegenbauer Processes and European Inflation Rates, May 2009

2649 Henning Bohn, A Static Model for Voting on Social Security, May 2009

2650 Markus Haavio and Kaisa Kotakorpi, The Political Economy of Sin Taxes, May 2009

2651 Augusto de la Torre, María Soledad Martínez Pería and Sergio L. Schmukler, Drivers and Obstacles to Banking SMEs: The Role of Competition and the Institutional Framework, May 2009

2652 Tobias Lindhe and Jan Södersten, Dividend Taxation, Share Repurchases and the Equity Trap, May 2009

2653 Assaf Razin and Edith Sand, Migration-Regime Liberalization and Social Security: Political-Economy Effect, May 2009

2654 Yin-Wong Cheung and Hiro Ito, A Cross-Country Empirical Analysis of International Reserves, May 2009

2655 Bart Cockx and Bruno Van der Linden, Flexicurity in Belgium. A Proposal Based on Economic Principles, May 2009

2656 Michael Melvin, Lukas Menkhoff and Maik Schmeling, Exchange Rate Management in Emerging Markets: Intervention via an Electronic Limit Order Book, May 2009

2657 Susanne Neckermann, Reto Cueni and Bruno S. Frey, What is an Award Worth? An Econometric Assessment of the Impact of Awards on Employee Performance, May 2009

2658 Steven Brakman, Harry Garretsen and Charles van Marrewijk, Economic Geography within and between European Nations: The Role of Market Potential and Density across Space and Time, May 2009

2659 Giovanni Facchini and Cecilia Testa, Reforming Legislatures: Is one House better than two?, May 2009

2660 Carsten Kowalczyk and Raymond Riezman, Trade Agreements, May 2009 
2661 Oliver Falck, Stephan Heblich and Elke Luedemann, Identity and Entrepreneurship, May 2009

2662 Christian Lessmann and Gunther Markwardt, One Size Fits All? Decentralization, Corruption, and the Monitoring of Bureaucrats, May 2009

2663 Felix Bierbrauer, On the Legitimacy of Coercion for the Financing of Public Goods, May 2009

2664 Alessandro Cigno, Agency in Family Policy: A Survey, May 2009

2665 Claudia M. Buch and Christian Pierdzioch, Low Skill but High Volatility?, May 2009

2666 Hendrik Jürges, Kerstin Schneider, Martin Senkbeil and Claus H. Carstensen, Assessment Drives Learning: The Effect of Central Exit Exams on Curricular Knowledge and Mathematical Literacy, June 2009

2667 Eric A. Hanushek and Ludger Woessmann, Schooling, Cognitive Skills, and the Latin American Growth Puzzle, June 2009

2668 Ourania Karakosta, Christos Kotsogiannis and Miguel-Angel Lopez-Garcia, Does Indirect Tax Harmonization Deliver Pareto Improvements in the Presence of Global Public Goods?, June 2009

2669 Aleksandra Riedl and Silvia Rocha-Akis, Testing the Tax Competition Theory: How Elastic are National Tax Bases in OECD Countries?, June 2009

2670 Dominique Demougin and Carsten Helm, Incentive Contracts and Efficient Unemployment Benefits, June 2009

2671 Guglielmo Maria Caporale and Luis A. Gil-Alana, Long Memory in US Real Output per Capita, June 2009

2672 Jim Malley and Ulrich Woitek, Productivity Shocks and Aggregate Cycles in an Estimated Endogenous Growth Model, June 2009

2673 Vivek Ghosal, Business Strategy and Firm Reorganization under Changing Market Conditions, June 2009

2674 Francesco Menoncin and Paolo M. Panteghini, Retrospective Capital Gains Taxation in the Real World, June 2009 